\title{
Effect of bovine colostrum intake on growth, reproductive parameters and survival in red kids
}

\author{
H. Abdou ${ }^{1}$, H. Marichatou ${ }^{2}$, J.-F. Beckers ${ }^{3}$, I. Dufrasne ${ }^{1}$, M. Issa ${ }^{4}$ and J.-L.Hornick ${ }^{1}$ \\ 1 Laboratory of Nutrition, Department of Animal Production, Faculty of Veterinary, University of Liege, Liege, Belgium \\ 2 Department of Animal Production, Faculty of Agriculture, University Abdou Moumouni, Niamey, Niger \\ 3 Laboratory of Reproductive Physiology, Department of Science Functional, Faculty of Veterinary, University of Liege, Liege, Belgium, and \\ 4 Department of Biology, Faculty of Science and Technology, University Abdou Moumouni, Niamey, Niger
}

\section{Summary}

The aim of this study is to evaluate the efficacy of frozen Azawak colostrum supplementation on body weight (BW), average daily gain (ADG), reproductive parameters (mean age at first parturition, fertility, fecundity, prolificacy) and mortality rate among red kids. The study was conducted at the goat farm secondary centre of Maradi in Niger from September 2010 to September 2011. The control animals $(n=20)$ were left with their mother, while the treatment animals $(n=20)$ received in addition $50 \mathrm{ml} /$ animal/day of bovine colostrum at birth and $15 \mathrm{ml} /$ animal/day from d2 to d15. Weight was measured weekly from birth to d365. Mortalities were also recorded over the same period. For reproductive parameters, observations began at weaning (d197). Growth rate was higher $(\mathrm{p}<0.001)$ in supplemented animal, and the treatment effects on ADG were observed up to 150 day after the end of supplementation. A similar long-lasting trend was also observed in relation to the mortality rate ( $25 \%$ for ColG vs. $55 \%$ for ConG; $p=0.05)$. The age at first kidding tended to be lower in the treated group $(13.8 \pm 0.7$ vs. $14.1 \pm 0.8$ month; $p<0.1)$. In conclusion, mild bovine colostrum supplementation induces a long-lasting positive impact on growth rate and to a lower extent on reproduction parameters and survival rate.

Keywords bovine, colostrum, growth performance, survival, red kids

Correspondence J.-L. Hornick, Laboratory of Nutrition Pets, Department of Animal Production, Faculty of Veterinary, University of Liege, 20 Boulevard de Colonster, Bldg. B43, 4000 Liege, Belgium. Tel: +32(0)43664131; Fax: +32(0)43664122; E-mail: jlhornick@ulg.ac.be

Received: 23 May 2013; accepted: 16 October 2013

\section{Introduction}

Colostrum is a high-value product in the diet of young suckling animals (Cairangzhuoma et al., 2013; Xu et al., 2013) in that it contains elements required for the survival and growth of the young animals (Sun et al., 2013). In general, the period from birth to weaning is a critical step for many mammals. The failure or delay in colostrum ingestion within hours after birth is a health risk that affects the future performance of the newborn animal (Le Huërou-Luron et al., 2004). In Niger, where rearing conditions are precarious, young animals frequently die within 1 month after birth. In 2010, unpublished statistics of the goat farm secondary centre in Maradi (GFSCM) stated that $76 \%$ of kids died before the age of 2 months. In such conditions, colostrum intake is critical early after birth (Xu et al., 2013). Supplementation of newborns with colostrum from other species is a potential pathway for improving performances in rearing kids (Jensen et al., 2013). Hence, we thought it interesting to assess the effect of supplementation with colostrum from other species on kids in the drought conditions prevailing in Niger. Therefore, the aim of this study is to evaluate the effect of supplementing bovine colostrum from Azawak Zebu to kids of Maradi red goats in Niger.

\section{Materials and methods}

\section{Experimental site}

The study was conducted at the GFSCM of Niger from September 2010 to September 2011 . The average prevailing daytime temperature was $35^{\circ} \mathrm{C}$, and average annual rainfall was between 600 and $700 \mathrm{~mm}$ ). The town of Maradi is located at approximately six hundred kilometres south-east of Niamey between $13^{\circ}$ and $15^{\circ} 26^{\prime}$ north latitude and $6^{\circ} 16^{\prime}$ and $8^{\circ} 33^{\prime}$ E longitude. The GSCFM was established in 1963 at approximately $3.5 \mathrm{~km}$, east of the town of Maradi and covers 
an area of 1850 ha. Kids are generally maintained, with their mothers, on semi-intensive rangeland in the day and kept in permanent sheds at night. The animals graze under the guidance of shepherds in the day and at night they receive a supplement of concentrates (wheat bran, cottonseed meal) twice a week. In addition, licks are permanently available in their racks. Water is provided ad libitum.

\section{Colostrum collection}

The colostrum (10 l) was obtained from Azawak Zebu cows at the Sahelian experimental station of Toukounous (SEST), two hundred kilometres north of Niamey. Colostrum was collected before the first suckling in containers, aliquoted into tubes and frozen in the first hours after collection. Cows were vaccinated against contagious bovine pleuropneumonia (CBPP) in July 2010. No known transmissible disease from cattle to sheep or goats was reported in 2010 at the SEST. Colostrum was analysed for chemical composition and immunoglobulin content (Table 1). Immunoglobulin (Ig) and lactoferrin (Lf) were measured using ELISA at the Center for Rural Economy of Marloie (Belgium), following the manufacturer's recommendations (Bethyl $^{\circledR}$ quantitative sandwich ELISA, Bethyl Laboratories, Inc., Montgomery, TX, USA). Dry matter (DM), ash, nitrogen-free extract (NFE), ether extract (EE) and crude protein (CP) were measured following the methods of the Association of Official Analytical Chemists (AOAC, 2006). Calcium (Ca) and magnesium $(\mathrm{Mg})$ were assessed through atomic absorption, and flame emission was used to measure

Table 1 Chemical composition and immunoglobulins content (means \pm standard deviation) in Azawak cows colostrum

\begin{tabular}{lc}
\hline Composition $(g / l)$ & Means \pm SD $(n \S=7)$ \\
\hline IgG & $22.5 \pm 1.7$ \\
IgA & $3.3 \pm 0.7$ \\
IgM & $1.7 \pm 0.7$ \\
Lactoferrin & $0.2 \pm 0.2$ \\
DM & $149.8 \pm 15.3$ \\
CP & $67.6 \pm 9.2$ \\
EE & $28.9 \pm 0.2$ \\
NFE & $43.4 \pm 3.2$ \\
ash & $9.9 \pm 0.7$ \\
Ca & $1.3 \pm 0.2$ \\
P & $1.3 \pm 0.2$ \\
K & $1.4 \pm 0.2$ \\
Na & $0.7 \pm 0.2$ \\
Mg & $0.2 \pm 0.0$ \\
\hline
\end{tabular}

DM, dry matter; CP, crude protein; EE, ether extract; NFE, nitrogen-free extract;

$\S n$, number of sample. potassium $(\mathrm{K})$ and sodium $(\mathrm{Na})$, and phosphorus $(\mathrm{P})$ was evaluated through spectrophotometry.

\section{Animals and experimentation}

The experimental protocol was approved by the laboratory of Animal production/Faculty of Agriculture/ University of Abdou Moumouni (Niamey-Niger) in collaboration with the directorate of Niger Veterinary Services. The study was performed on 40 kids born from 17 September 2010 to 31 October 2011. Each animal was identified by an alphanumeric number indicating its affiliation in the park, its year and order of birth and its sex. At each birth, kids were randomly allocated to either the control group (ConG) or the experimental group (Colostrum group, ColG), but in a way to maintain sex equilibrium in the allocation, all kids were allowed to stay with their mothers and suck ad libitum; water was also provided ad libitum. At birth $(\mathrm{d} 1)$, kids allocated to ColG received orally a supplement of $50 \mathrm{ml} / \mathrm{animal} /$ day of bovine colostrum, divided into two meals, and $15 \mathrm{ml} / \mathrm{ani}$ $\mathrm{mal} /$ day from $\mathrm{d} 2$ to $\mathrm{d} 15$.

\section{Control parameters}

To assess the effect of colostrum on kid growth, animals were weighted weekly in first month after birth and then biweekly until d365, using a scale with a maximum loads of $150 \pm 0.1 \mathrm{~kg}$. Mean age at first kidding (MAFK), fecundity (proportion of females giving birth on total females subjected to reproduction), fertility (proportion of pregnant females on total females subjected to reproduction) and prolificacy (offspring per female) was also recorded for females issued from the kid population. In males, no parameters of reproduction were measured. Death occurrences were recorded daily during the study to assess the effect of colostrum on survival rate.

\section{Statistical analysis}

Data were analysed using a mixed model of the Statistical Analysis System (SAS, 1999) including the effects of treatment, time, sex and allowing the inclusion of a type 1 autoregressive effect for repeated data measured on the same animal. For MAFK, the arithmetic means were calculated. The Student's $t$-test was used to compare averages. For fecundity and mortality, data were analysed by chi-square test. Growth performance at three stages (supplementation, post-supplementation to weaning and weaning to the end of the study) was analysed using the general linear model 
procedure of the Statistical Analysis System (SAS, 1999).

\section{Results}

\section{Growth}

Table 2 shows the animal performances at the three consecutive stages: supplementation (stage 1), postsupplementation to weaning (stage 2) and weaning to the end of the study (stage 3). During supplementation, the initial body weight (BW) was similar between groups $(p>0.05)$. Final weight at this stage reached higher values in ColG than in ConG $(+$ $1.57 \pm 0.06 \mathrm{~kg}, \mathrm{p}<0.001)$, with ADG largely higher $100.4 \pm 4.4$ vs. $74.7 \pm 4.4 \mathrm{~g} / \mathrm{d})$.

From d 15 to weaning (d197), the ADG continued to be higher in ColG than in ConG (62.8 vs. $46.4 \mathrm{~g} / \mathrm{d})$, although during this transitional stage, ADG decreased in both groups $(-37.4 \%$ and $-37.8 \%$ in ColG and ConG respectively). This helped the treatment animals to reach a live weight close to $14.6 \pm 0.17 \mathrm{~kg}$ achieving, hence, a supplemental $3.4 \mathrm{~kg}$ over animals of the other group ( $14.6 \pm 0.17$ vs. $11.2 \pm 0.2 \mathrm{~kg}, \mathrm{p}<0.001)$.

In the last stage, total gain remained significantly higher in ColG $(p<0.001)$, as well as ADG
$(41.4 \pm 0.8$ vs. $34.9 \pm 0.8 \mathrm{~g} / \mathrm{d}, \mathrm{p}<0.001)$, resulting in an overall weight gain of $6.6 \mathrm{~kg}$ for ColG over ConG $(\mathrm{p}<0.001)$.

The trend evolution of BW and ADG for red kids of the two groups is given in Fig. 1. During all the experiment, the growth curves were quasi-linear, but with different slopes, whereby weight differences increased with time, starting from the second week of the experiment. The development of ADG varied at different stages. It was as high as approximately $100.4 \mathrm{~g} / \mathrm{d}$ at the beginning of the experiment, but decreased thereafter regularly with time to reach a plateau of approximately $41.4 \mathrm{~g} / \mathrm{d}$ at the 10 th month. The ADG differences between the two groups were strong, even during the post-supplementation stage, until approximately d127 after birth, and more variable thereafter, the effect disappeared after $\mathrm{d} 300$.

\section{Reproductive parameters}

Means values of MAFK were $(13.8 \pm 0.7$ vs. $14.1 \pm 0.8$ month; $\mathrm{p}<0.1)$, respectively, for ColG and ConG. By contrast, for parameters such as fecundity, fertility and prolificacy, there was no difference between the two groups of females.

Table 2 Performances of red kids that received or not a supplement of bovine colostrum during the first 15 days of live in Maradi, Niger

\begin{tabular}{|c|c|c|c|c|c|c|c|c|}
\hline \multirow[b]{3}{*}{ Item } & \multicolumn{4}{|l|}{ Groups } & & & & \multirow[b]{3}{*}{ SEM } \\
\hline & \multicolumn{2}{|l|}{ ColG } & \multicolumn{2}{|l|}{ ConG } & \multicolumn{3}{|c|}{$p>F$} & \\
\hline & Male $(n \S=11)$ & Female $(n \S=9)$ & Male $(n \S=8)$ & Female $(n \S=12)$ & $T^{*}$ & $\mathrm{~S}^{\dagger}$ & $\mathrm{T}^{\star} \times \mathrm{S}+$ Interaction & \\
\hline \multicolumn{9}{|l|}{ Period 1: Birth to d15 } \\
\hline BW at birth, kg & 1.7 & 1.6 & 1.5 & 1.6 & ns & ns & ns & 0.1 \\
\hline BW at d15, kg & $3.2^{\mathrm{A}}$ & $3.2^{\mathrm{A}}$ & $2.7^{\mathrm{B}}$ & $2.7^{B}$ & $\star * \star$ & ns & ns & 0.1 \\
\hline Total gain, kg & $1.4^{\mathrm{A}}$ & $1.6^{\mathrm{A}}$ & $1.1^{\mathrm{B}}$ & $1.2^{\mathrm{B}}$ & $* * *$ & $\dagger$ & ns & 0.1 \\
\hline ADG, g/day & $95.0^{\mathrm{A}}$ & $105.8^{A}$ & $70.0^{\mathrm{B}}$ & $79.3^{B}$ & $* \star \star$ & ns & ns & 5.7 \\
\hline Number of kids at d15 & 8 & 8 & 6 & 8 & & & & \\
\hline \multicolumn{9}{|c|}{ Period 2: d15 to d197 (weaning) } \\
\hline BW at d15, kg & $3.2^{\mathrm{A}}$ & $3.2^{\mathrm{A}}$ & $2.7^{\mathrm{B}}$ & $2.7^{\mathrm{B}}$ & 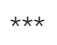 & ns & ns & 0.1 \\
\hline BW at d197, kg & $14.8^{\mathrm{A}}$ & $14.4^{\mathrm{A}}$ & $11.8^{\mathrm{aB}}$ & $10.6^{\mathrm{bB}}$ & $* * *$ & ** & ns & 0.2 \\
\hline Total gain, kg & $11.7^{\mathrm{A}}$ & $11.2^{\mathrm{A}}$ & $9.0^{\mathrm{aB}}$ & $7.8^{\mathrm{bB}}$ & $* * *$ & * & ns & 0.3 \\
\hline ADG, g/day & $64.1^{\mathrm{A}}$ & $61.5^{\mathrm{A}}$ & $49.6^{\mathrm{aB}}$ & $43.3^{\mathrm{bB}}$ & $* * *$ & * & ns & 1.6 \\
\hline Number of kids at d197 & 7 & 8 & 3 & 7 & & & & \\
\hline \multicolumn{9}{|c|}{ Period 3: $d 197$ (weaning) to $d 365$ (the end of study) } \\
\hline BW at d197, kg & $14.8^{\mathrm{A}}$ & $14.4^{\mathrm{A}}$ & $11.8^{\mathrm{aB}}$ & $10.6^{\mathrm{bB}}$ & *** & ** & ns & 0.2 \\
\hline BW at d $365, \mathrm{~kg}$ & $21.8^{\mathrm{aA}}$ & $21.2^{\mathrm{bA}}$ & $18.5^{\mathrm{aB}}$ & $16.4^{\mathrm{bB}}$ & $\star * *$ & $* * *$ & * & 0.2 \\
\hline Total gain, kg & $7.2^{\mathrm{A}}$ & $6.8^{\mathrm{A}}$ & $6.2^{\mathrm{aB}}$ & $5.5^{\mathrm{bB}}$ & $\star \star \star *$ & $\star$ & ns & 0.4 \\
\hline ADG, g/day & $42.7^{\mathrm{A}}$ & $40.1^{\mathrm{A}}$ & $36.9^{\mathrm{aB}}$ & $32.8^{\mathrm{bB}}$ & $\star \star *$ & * & ns & 0.8 \\
\hline Number of kids at d365 & 7 & 8 & 3 & 6 & & & & \\
\hline
\end{tabular}

ADG, average daily gain; BW, body weight; $n$, number of sample; ${ }^{\star} T$, Treatment; $\uparrow S$, Sex; ${ }^{\star \top} \times \dagger S$, Treatment $\times$ Sex (interaction).

ns, not significant $(p>0.05) ; \uparrow(p<0.1) ; *(p<0.05) ; * *(p<0.01) ; * * *(p<0.001)$.

${ }_{a, b}$ For a same treatment and same line, values assigned to two different small letters are significantly different $(p<0.05)$.

${ }^{A}, \mathrm{~B} F$ For a same sex and same line, values assigned to two different capital letters are significantly different $(p<0.05)$. 


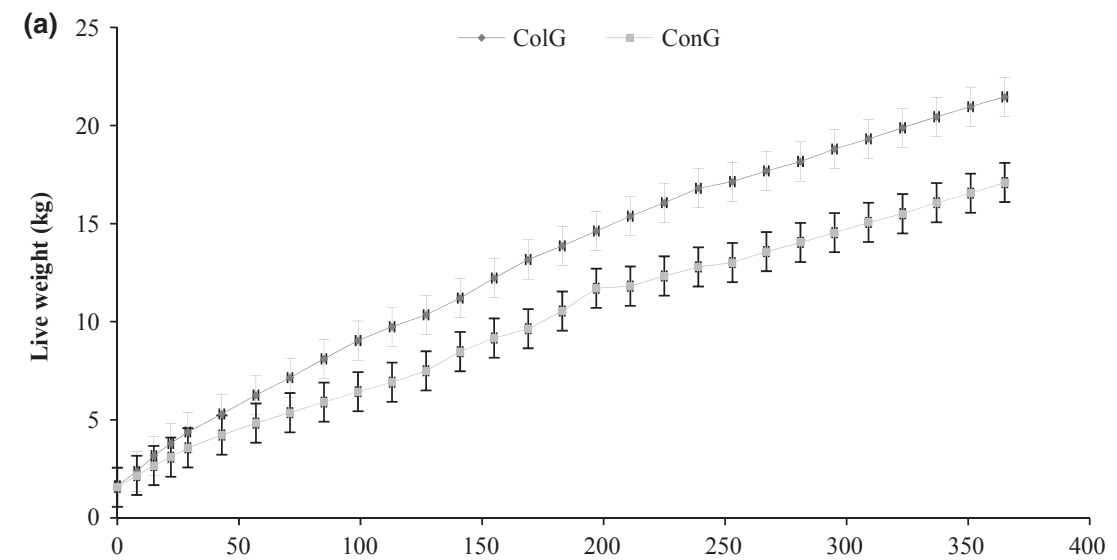

(b)

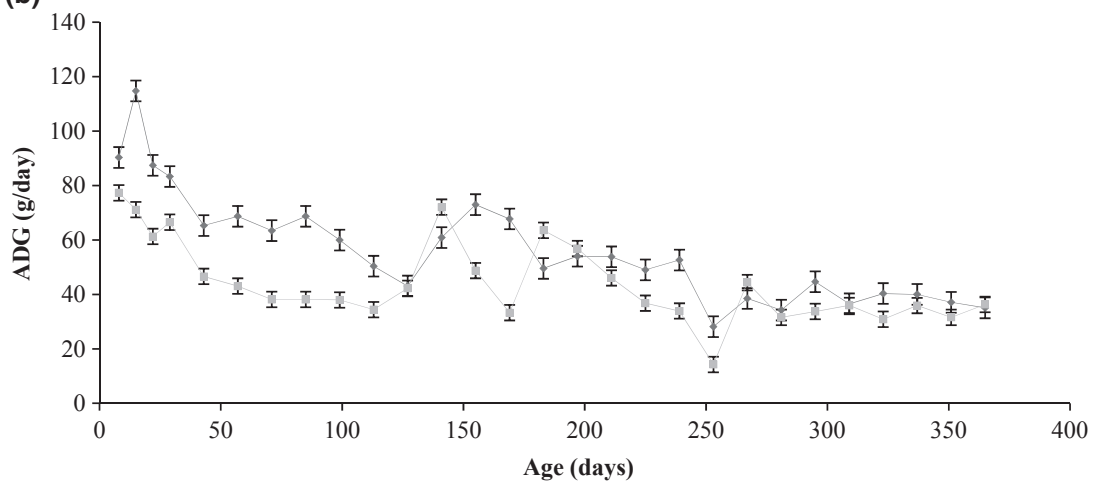

Fig. 1 Evolution of body weight (a) and average daily gain (ADG) (b) of red kids that received or not a supplement of bovine colostrum during the first 15 days of live in Maradi, Niger. The values are expressed as least squares means \pm se (standard error).

\section{Survival rate}

Mortality rate in ColG was significantly lower than in ConG and lower than values observed in previous years (Fig. 2). Five (5) animals died in ColG compared to 11 in ConG, that is, a $30 \%$ reduction in mortality rate. Statistical analysis revealed a quasi-effect in favour of ColG $(p=0.05)$. For both treatments, the death risk period was at the supplementation stage, when two casualties (10\%) were recorded in ColG and $6(30 \%)$ in ConG. From supplementation to weaning, the death rate in ColG remained unchanged $(10 \%)$, whereas in ConG, it decreased to $20 \%$. At the last stage (weaning to end of study), the rate was similar $(5 \%)$ for both groups. Casualties occurred after diarrhoeal enteritis $(35.3 \%)$, respiratory diseases $(25 \%)$ and unknown reasons $(43.75 \%)$. Figure 3 shows the evolution of kid survival rate in the two groups.

\section{Discussion}

\section{Growth}

This study that aims to evaluate the effects of bovine colostrum from Azawak breed on red kids was never reported in the literature, to our knowledge. Boudry et al. (2008a) and Abdou et al. (2012) reviewed the large potential of bovine colostrum for heterologous use.

Bovine colostrum is the natural food for neonatal calves. In addition, bovine colostrum was used as a supplement in young animals of other species to improve health and development (Le Huërou-Luron et al., 2004 and Boudry et al., 2005, 2008b). In calves, a lot of studies were carried out to indicate the importance of colostrum feeding on growth and development (Blum and Hammon, 2000; Blum, 2006; Berge et al., 2008; Moretti et al., 2010; Machado-Neto et al., 2011). The authors associated these differences to the effects of the numerous components in high or low concentrations, such as immunoglobulin, nutrients and factors like epidermal growth factor (EGF), insulin-like grown factor (IGF-1) and transforming growth factor (TGF), which are known to be involved in the stimulation of intestinal tissue. The study by Moretti et al. (2013) showed that supplementation with lyophilized bovine colostrum increased cell maturity in the enteric and muscle tissues in the first hours of kid life. In addition, the work of Le HuërouLuron et al. (2004) showed that bovine colostrum effect was strengthened when animals were reared in poor conditions. In their respective conclusions, these authors suggested the inclusion of bovine colostrum 
(a)

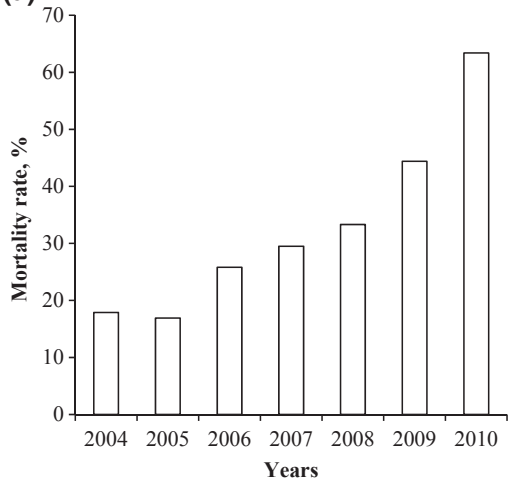

(b)

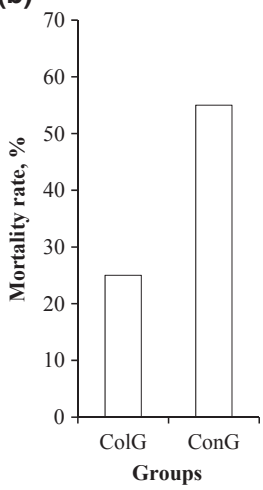

Fig. 2 Mortality observed from 2004 to 2010 in CMBSC (a) and during the experiment (b).

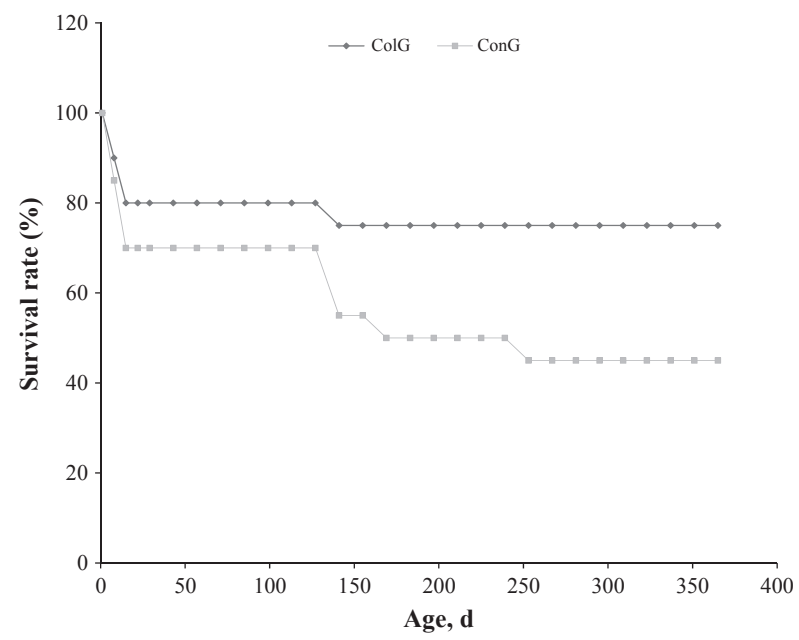

Fig. 3 Evolution of survival rate of kids that received or not a supplement of colostrum during the first 15 days of live in Maradi, Niger.

in neonatal or post-weaning feed of young animals because of its high content in nutrients and its huge effects on animal growth performance.

The data obtained in this study are in line with those obtained by the authors mentioned above. Surprisingly, the positive effect of colostrum on live weight was maintained during the whole period of observation, that is, long after the end of the colostrum supplementation, suggesting a memory effect on animals.

For ADG, positive effects of colostrum were particularly noted in the two-first weeks of supplementation, but were also paradoxically maintained all over the trial, especially considering the mean values per stage. The first-stage effect could be explained by the intrinsic characteristics of bovine colostrum (its high grade nutrient value and digestibility). It provides to newborns two times more energy than the same amount of milk and contains less lactose, which helps prevent the occurrence of diarrhoea (Blum and Hammon, 2000). The study of Le Dividich et al. (1989) showed that piglets express hypoglycaemia at birth which is quickly solved with the first ingestion of colostrum. They linked this increase to an endogenous glucose production through the mobilization of glycogen reserves by liver and to exogenous income of lactose rapidly hydrolysed into glucose and galactose (Hammon et al., 2013). In addition, it is known that a large fraction of colostrum proteins are immunoglobulin (IgG, IgA) that give newborns immunity not only locally, but also against gastrointestinal pathogens. It also provides systemic immunity against infectious agents and septicaemia (Blum and Hammon, 2000).

In the present experiment, the increase in ADG was low but significant (ranging from approximately 25-5 g/d) over a long period. The supplementation with colostrum also had significant positive effects on growth throughout the trial. If the positive effect could be attributed to the nutritional value and especially the energetic value $(6.0 \mathrm{MJ} / \mathrm{l})$ of bovine colostrum (Blum and Hammon, 2000), this nutritional value cannot explain the long-lasting effect since the $15 \mathrm{ml}$ colostrum offered daily to kids represented approximately $0.09 \mathrm{MJ} / \mathrm{l}$, that is, only $6.8 \%$ of the daily energy requirement for a newborn growing kid. Consequently, the long-lasting weight increase in kids of ColG could only be explained by a catalytic effect of nutrients (protein, fat, lactose, vitamins and minerals), antibodies, other non-specific antimicrobial or endocrine elements (lactoferrin, lactoperoxidase, lysozyme, IGFs), and other pseudo-paracrine and autocrine factors contained in the bovine colostrum. It is known that ingestion of colostrum enhances gastrointestinal tract development and function (Blum and Hammon, 2000) and stimulates newborns' immune system (Le Huërou-Luron et al., 2004), resulting in a histological maturation of lymphoid organs; it also increases the size of Peyer's patches and improves differentiation between the cortex and medulla of lymphoid nodes (Marion et al., 2002). Besides its direct nutritional and immune roles, other functions are attributed to colostrum. For example, it takes part in the synthesis of thyroid hormones (Hadorn et al., 1997) owing to the fact that it contains a significant amount of iodine and selenium which are required for their metabolism (Boland et al., 2005). The bestknown growth factors contained in colostrum are the IGF-1 and 2. They are involved in the stimulation of cell growth and multiplication in the intestinal sphere 
of newborns (Boudry et al., 2008a). In addition, the study of Burrin et al. (1992) showed that oral administration of IGF-1 in newborn piglets increases villus height in proportion with the dose.

\section{Reproductive parameters}

Several authors addressed colostrum intake on animal performance and immune system, but to our knowledge no work dealt with the effect of colostrum on reproductive parameters. The effects of proteo-energy supplementation alone on MAFK are hardly showed in red goats. Fasanya et al. (1992) found that a supplement of cotton seed cake (CSC) alone improved MAFK value, but not a mixture of CSC and maize, or maize alone. Our results showed a weak effect associated with bovine colostrum intake on reproductive parameters. Indeed, goats in the colostrum group tended to be more mature than those in the control group, and other animals studied at the station (MAFK value of 20 and 14.5 months, respectively, observed by Verhulst in 1995 and Naba in 2001). However, no effect could be observed on fecundity, fertility and prolificacy. Reproductive parameters largely depend on animal growth rate (BW and $\mathrm{ADG}$ ) and speed to puberty weight. The improvement of live weight and ADG depends on nutritional values of intake such as colostrum which contains nutrients and antipathogenic compounds (Blum and Hammon, 2000; Boudry et al., 2008a). As mentioned above, the supplementation provided in this experiment was quantitatively weak, but it induced significant changes in live weight, leading to expect changes in reproduction parameters. For fecundity, the average value obtained in ColG was greater than in ConG, but this difference was only a trend. Value of fecundity and fertility was in line with the data recorded at GFSCM (80.34\%) in 1992, (109.96\%) in 1993 and reported by Hamidou (1995). As for prolificacy, the results of this study are considerably lower than those obtained by Verhulst (1995); Marichatou et al. (2002) on red goats. This may be attributed to litter size. It is known in the literature that in red goats, twinning is very scarce at first kidding (Naba, 2001). Finally, females should be monitored during a longer period, to evaluate the effect of colostrum supplementation on reproductive performances.

\section{Survival rate}

The use of bovine colostrum seemed interesting as a mean to reduce neonatal mortality and therefore increases chances of survival in newborn kids of traditional and modern farms. To our knowledge, very few experiments on goat survival were performed in Niger, and the effect of colostrum on mortality is little known, particularly, in red kids. In the Sahel, feed is a limiting factor in farms (Mcdowell et al., 1983). An overview of the evolution of mortality rates at GFSCM for the past 7 years shows all the interest colostrum supplementation could bear for improving the health status of red kids. During the period mentioned above, the mortality rate evolved as shown in Fig. 2a. The rate ranged from $17.9 \%$ to $63.6 \%$. In our study, for ConG, the mortality rate from do to d365 recorded by Naba (2001) was of 44\% at GFSCM and $60 \%$ in surrounding small farms. By contrast, in the ColG, the value was drastically reduced to $26 \%$.

The difference between the two groups would likely be attributed to the supplementation of colostrum that ensured a local protection of kids. The study by Boudry et al. (2008b) where 96 piglets weaned at $26 \pm 2$ days of age were subjected for 4 weeks to a control regimen or a regimen with lyophilized bovine colostrum showed that the supplemented group was healthier and showed a reduced mortality rate. In addition, this study showed a link between a shortterm supplementation in heterologous colostrum and mortality rate.

Again, the positive effects resulted probably from the supplemental action of antimicrobial factors present in additional colostrum, particularly IgG which represents approximately $95 \%$ of immunoglobulin (Boudry et al., 2008a), but also lactoferrin, lactoperoxidase, lysozyme, cytokine. The long-lasting effect of colostrum intake on mortality rate in ColG suggests also the so-called 'catalytic effect' of the various compounds found in the colostrum, as described above for animal performance. Finally, data from this study corroborate results of (Lima et al., 2009) which found that a supplement of bovine colostrum to kids at birth increased the levels of plasma immunoglobulins. They suggested that bovine colostrum can be used as an alternative source of initial protection for newborn goat kids.

\section{Conclusion}

The results of this study show that supplementation of bovine colostrum during a short time of neonatal period can improve the performance and reduce the mortality rate of kids. The response to supplementation results in a sustainable increase in BW and ADG and a significant decrease in mortality. Presumably, the amount of colostrum and the length of the experi- 
ment may have an effect on the results. Further studies should be conducted to take into account those parameters and to observe the effect of early supplementation on reproduction parameters of multiparous females, during short time of the neonatal period.

\section{Acknowledgements}

The authors thank the Belgian Technical Cooperation (BTC) for its financial support.

\section{References}

Abdou, H.; Marichatou, H.; Beckers, J.-F.; Dufrasne, I.; Hornick, J.-L., 2012: Physiology of the production and chemical composition of colostrum of domestic mammals. Annales de Médecine Vétérinaire 156, 87-98.

AOAC, 2006: Association of Official Analytical Chemists, 18th edition, Current Through Revision 1. AOAC International, Arlington, VA. 28 pp.

Berge, A. C. B.; Besser, T. E.; Moore, D. A. Sischo, W. M., 2008: Evaluation of the effects of oral colostrum supplementation during the first fourteen days on the health and performance of preweaned calves. Journal of Dairy Science 92, 286-295.

Blum, J. W., 2006: Nutritional physiology of neonatal calves. Journal of Animal Physiology and Animal Nutrition 90, 1-11.

Blum, J. W.; Hammon, H. M., 2000: Colostrum effects on the gastro-intestinal tract, and on nutritional, endocrine and metabolic parameters in neonatal calves. Livestock Production Science 66, 151-159.

Boland, T. M.; Brophy, P. O.; Callan, J. J.; Quinn, P. J.; Nowakowski, P.; Crosby, T. F., 2005: The effects of mineral supplementation to ewes in late pregnancy on colostrum yield and immunoglobulin $\mathrm{G}$ absorption in their lambs. Livestock Production Science 97, 141-150.

Boudry, C.; Dalle, M. J.; Halleux, C.; Porteltelle, D.; Alfred, A. C.; Havaux, X.; Giannello, P.; Thewis, A.; Bulgen, A.; Dehoux, J. P., 2005: Effect of bovine colostrum on the morphology of the intestinal wall and the immune system when given to piglets at weaning. Journées Recherche Porcine en France 37, 219-224.

Boudry, C.; Dehoux, J. P.; Portetelle, D.; Bulgen, A., 2008a: Bovine colostrum as a natural growth promoter for newly weaned piglets. Biotechnologie Agronomie Societé et Environement 12, 157-170.

Boudry, C.; Dehoux, J. P.; Wavreille, J.; Portetelle, D.; Thewis, A.; Bulgen, A., 2008b: Effect of a bovine colostrum whey supplementation on growth per- formance, faecal Escherichia coli population and systemic immune response of piglets at weaning. Animal 2, 730-737. Burrin, D. G.; Schulman, R. J.; Reeds, P. J.; Davis, T. A.; Gravitt, K. R., 1992: Porcine colostrum and milk stimulate visceral organ and skeletal muscle protein synthesis in neonatal piglets. Journal of Nutrition 122, 12051213.

Cairangzhuoma Yamamoto, M.; Xijier, Inagaki, M.; Uchida, K.; Yamashita, K.; Saito, S.; Yabe, T.; Kanamaru, Y., 2013: A Preparation of Cow's late colostrum fraction containing alpha sl-casein, promoted the proliferation of cultured rat intestinal IEC-6 epithelial cells. Bioscience, Biotechnology, and Biochemistry 77, 120942-1-6.

Fasanya, O. O. A.; Molokwu, E. C. I.; Eduvie, L. O., 1992: Dietary supplementation in the Savanna brown goat. II. Gestation and postpartum activity in primiparous does. Animal Reproduction Science 29, 167-174.

Hadorn, U.; Hammon, H.; Bruckmaier, R. M.; Blum, J. W., 1997: Delaying colostrum intake by one day has important effects on metabolic traits and on gastrointestinal and metabolic hormones in neonatal calves. Journal of Nutrition 127, 2011-2023.

Hamidou, I., 1995: Contribution à l'analyse des paramètres de reproduction de la chèvre rousse de Maradi (Niger). (Thèse de doctorat vétérinaire). Ecole Inter-États des Sciences et Médecine Vétérinaire de Dakar, Dakar, Sénégal.

Hammon, H. M.; Steinhoff-Wagner, J.; Flor, J.; Schönhusen, U.; Metges, C. C., 2013: Role of colostrum and colostrum components on glucose metabolism in neonatal calves. Journal of Animal Science 91, 685-695.

Jensen, M. L.; Sangild, P. T.; Lykke, M.; Schmidt, M.; Boye, M.; Jensen, B. B.; Thymann, T., 2013: Similar efficacy of human banked milk and bovine colostrum to decrease incidence of necrotizing enterocolitis in preterm piglets. Regulatory integrative and comparative physiology. American Journal of Physiology 305, R4-R 12 (in press).
Le Dividich, J.; Esnault, T.; Lynch, B., 1989: Influence de la teneur en lipides du colostrum sur l'accrétion lipidique et la régulation de la glycémie chez le porc nouveau-né. Journées Recherche Porcine en France 21, 275-280.

Le Huërou-Luron, I.; Hughet, A.; Callarec, J.; Leroux, T.; Le Dividich, J., 2004: Supplementation of a weaning diet with bovine colostrum increases feed intake and growth of weaned piglets. Journées Recherche Porcine en France 36, 33-38.

Lima, A. L.; Pauletti, P.; Susin, I.; Machado Neto, R., 2009: Fluctuation of serum variables in goats and comparative study of antibody absorption in new-born kids using cattle and goat colostrum. Journal Revista Brasileira de Zootecnia 38, 22112217.

Machado-Neto, R.; Grigolo, I. H.; Moretti, D. B.; Kindlein, L.; Pauletti, P., 2011: Intestinal histology of Santa Ines lambs fed bovine or ovine colostrum. Czech Journal of Animal Science 56, 465-474.

Marichatou, H.; Mamane, L.; Banoin, M.; Baril, G., 2002: Zootechnical performances of goats in Niger: comparative study of the Maradi Russet goat with the black-coat goat in Maradi area. Revue d'élevage et de médecine vétérinaire des pays tropicaux $\mathbf{5 5}, 79-84$.

Marion, J.; Le Huërou-Luron, I.; A. Huguet, A.; Callrec, J.; Leroux, T.; Le Dividich, J., 2002: Supplementation of a weaning diet with a bovine colostrum extract increased villi heights in the duodenum of weaned piglets. Journées Recherche Porcine en France 34, 103-108.

Mcdowell, R. L.; Conrad, J. H.; Ellis, L.; Lookli, J. K., 1983: Minerals for Grazing Ruminants in Tropical Regions. Library of Congress Catalog Card Number 8470238, University of Florida, Gainsville, FL.

Moretti, D. B.; Kindlein, L.; Pauletti, P.; Machado-Neto, R., 2010: IgG absorption by santa Ines lambs fed holstein bovine colostrum or Santa Ines ovine colostrum. Animal 6, 933-937.

Moretti, D. B.; Nordi, W. M.; Lima, A. L.; Pauletti, P.; Machado-Neto, R., 2013: Enteric, hepatic and muscle tissue development of goat kids fed with 
lyophilized bovine colostrum. Journal of Animal Physiology and Animal Nutrition 25, doi:10.1111/jpn. 12059.

Naba, A. M., 2001: Contribution à l'évaluation technique du projet d'appui à la sélection, la promotion et la diffusion de la chèvre rousse de Maradi-Niger (Thèse de doctorat vétérinaire). Ecole Inter-États des Sciences et Médecine Vétérinaire de Dakar, Dakar, Sénégal.
SAS, 1999: Statistical Analysis System. User's guide (5th edn, 8.2 version). SAS/STAT. Cary, NC.

Sun, Q.; Chen, X.; Yu, J.; Zen, K.; Zhang, C. Y.; Li, L., 2013: Immune modulatory function of abundant immune-related microRNAs in microvesicles from bovine colostrum. Protein e Cell 4, 197-210.

Verhulst, A., 1995: Appui à la sélection, à la promotion et à la diffusion de la chèvre rous- se de Maradi. Institut Voor Tropische Geneeskunde (Ivtg) d'Anvers, Anvers, Belgium.

Xu, M. L.; Kim, H. J.; Chang, D. Y., 2013: The effect of dietary intake of the acidic protein fraction of bovine colostrum on influenza a (H1N1) virus infection. Journal of Microbiology. doi:10.1007/s122 75-013-2683-y. 